Lea Leppik

\title{
UNIVERSITY OF TARTU PROFESSOR IN THE UNIVERSITY LANDSCAPE (IN THE FIRST THIRD OF THE $19^{\text {TH }}$ CENTURY)
}

The professors, students, study buildings and necessary auxiliary services of a university town form the mental and physical structure that can be called the university landscape. This article endeavours to determine the position of the professor on this landscape. First and foremost, we will discuss the mental landscape, i.e., the professor's social position in the state, the city and the university. We will also take a cursory glance at the location of the professors' residences in the city. The social position of the University of Tartu's professors in the $19^{\text {th }}$ century has yet to receive much attention in literature. On the other hand, several recent Russian publications speak directly or indirectly about the University of Tartu. ${ }^{1}$ This article focuses on the legal rights and obligations of the professors' community and the status derived therefrom, while the professors' material everyday life will be discussed in a future paper.

At the time the University of Tartu was reopened in 1802, several competing university models were developing in Europe. Closing

DOI: https://doi.org/10.12697/BJAH.2018.16.03

1 See for example, Tanya Kostina, 'Kachestvo zhizni universitetskogo professsora pervoj poloviny XIX v. (na primere Kazanskogo universiteta)', Sankt-Peterburgskij universitet $v$ XVIII$X I X$ v. Evropejskie tradicii i Rossijskij kontekst (St. Peterburg: Izdatelstvo Sankt Peterburgskogo universiteta, 2009), 57-73; Galina Kichigina, The Imperial Laboratory: Experimental Physiology and Clinical Medicine in Post-Crimean Russia (Amsterdam, NewYork: Rodopi, 2009), 23-26. 
or reorganising the old European universities between 1789 and 1815 had shrunk their numbers from 143 to 83 . On the other hand, new universities were already being founded. In a way, all the new models were based on the ideas of the Enlightenment, but their interactions with various political and social conditions yielded very different results at various locations. Politically fragmented Germany was moving towards a model that stressed the freedom of teaching and learning, the ultimate purpose of which was to serve scientific truth and free the universities of both religious and bureaucratic control. Revolutionary France saw universities as symbols of the Ancien Régime, and in contrast, idealised utilitarian education that focused on spreading useful knowledge, and was closely tied to satisfying the state's practical needs. Ideally, a professor at a renewing German university was a priest of independent truth, while a lector at a specialised French institution of higher education was first and foremost a public servant.

Since the professors of the reopened $19^{\text {th }}$ century University of Tartu had a say in establishing their rights and obligations, it is a good model for studying how the ideas of the time reached, or did not reach, local practice. The University of Tartu was the first new university opened in the Russian Empire, ${ }^{2}$ becoming an important trendsetter. In addition, the reopened university provided the warand fire-ravaged Tartu with the incentive to develop.

The university, which founded by the Swedes in 1632, was evacuated to Pärnu because of the Great Northern War in 1699, where it closed down in 1710. Although the territory of Estonia passed to the Russian state after the war, the Baltic provinces of Estonia and Livonia kept their Lutheran faith, German as the official language and an autonomous administrative and legal system. The German-speaking elite were able to send their sons to study at German universities, but after receiving their education abroad, they needed to adjust to the local circumstances. A local university was seen as an ideal way to maintain the special ecclesiastic and legal system of the Baltic provinces. The local Ritterschafts (Knighthoods), as well as the Tartu town government, had tried to reopen the

2 The first Russian university was the academic University in St Peterburg (1725), the second was Moscow (1755). In the early $19^{\text {th }}$ century several new universities were opened or old ones reopened: Tartu 1802, Vilnius 1803, Kazan 1804, Kharkiv 1805. After incorporating the Province of Finland in 1809, the University of Turku was added. 
university throughout the $18^{\text {th }}$ century, ${ }^{3}$ but this did not come to pass until the early $19^{\text {th }}$ century, when the Russian Empire - mostly in the fear of the French Revolution - started to focus on opening new universities in the state.

\section{THE LEGAL DEFINITION OF THE PROFESSORS' RIGHTS AND OBLIGATIONS}

When the University of Tartu was reopened in 1802, luring respected professors to this small provincial town away from the metropolises of Europe proved to be a real challenge. One should not forget that Europe was at war. Therefore, the professors of the university were given a series of privileges. ${ }^{4}$ The local knighthoods, who also administered the unique legal and religious system of the Baltic provinces, were willing to maintain the university. The knighthoods' plan for founding a Protestant university, which was prepared on 4 May $1799^{5}$, presupposed that all of its members would be exempt from personal taxes and the professors' houses would be freed from the duty to billet soldiers. The university was allowed to have its own printing house and censorship committee for its writings, and the professors, deans and pro-rector were to granted the same service rank as the respective officials at the Imperial Academy of Arts. Professors' widows would receive a 'widow's year' - one year's pension after her husband's death in the amount of his annual salary. The university would be subject directly to the Governing Senate (of the Russian Empire) and have limited autonomy, i.e. the right to decide internal matters, except those related to policing, civil and criminal matters. Most of the matters concerning the university's personnel and principal work remained under the jurisdiction of the board of curators comprised of the

3 See: Lea Leppik, 'Ülikool enne ülikooli', Johann Wilhelm Krause 1757-1828, kataloog 3: linnaehitajana Tartus = Als Stadtbauer in Tartu, ed. by Juhan Maiste, Anu Ormisson-Lahe (Tartu, Tallinn: Eesti Keele Sihtasutus, 2011), 59-82.

4 These privileges really worked, especially in 1806-1815. Tatjana N. Zhukovskaja, 'Universitety v gody Napoleonovskih voin', Sankt-Peterburgskij universitet v XVIII-XX vv.: evropejskije tradicii i rossijskij kontekst. Trudy mezhdunarodnoj nauchnoj konferencii 23-25 ijunja 2009 (Sankt-Peterburg: Sankt-Peterburgskij universitet, 2009), 22-37, here 22.

5 Complete Collection of Laws of the Russian Empire [Polnoe Zobranie Zakonov Rossijskoj Imperii, PSZ], I, nr. 18953. 
representatives of the knighthoods - they had the right to employ professors, monitor teaching and the professors' moral standing. And all the knighthood members would be granted the use of the university's library. A vice-curator elected by the curators would work permanently at the university and be responsible for financial matters. The professors themselves would have little say in the matter - they would hold the post of pro-rector (in rotation), whose main tasks were accepting students and electing the chairman of the council of professors. Thus, the curators, who represented the knighthoods, wished to maintain nearly total control over the university and the professors were to be hired as service personnel. As far as rank was concerned, being exempted from taxes and having the status of public officials would have placed them among the elite, or at least, the upper middle class.

In reality, this programme did not last long - when the Protestant university was finally opened in Tartu in the spring of 1802 after lengthy disputes, the original plan had already been significantly changed. Emperor Alexander I (reigned from 1801 to 1825) wished to be an enlightened monarch and his ascension to the throne in 1801 resulted in various new freedoms. This was also reflected in the amendments to the statutes of the University of Tartu (approved on 5 January 1802), ${ }^{6}$ which expanded the rights of the council of professors somewhat - it now had the right to decide on matters related to teaching and the council could elect a pro-rector (the post was no longer held in rotation). The university's censorship committee was given the right to freely order books from abroad. The opening celebrations were held on April $21^{\text {st }}$ and $22^{\text {nd }}$. Before that, the professors had demanded that they be allowed to give their pledge to the representative of the Russian state (governor), not the knighthoods' board of curators. ${ }^{7}$ The desire to be in the service of the Russian state instead of the local provincial government should be considered significant.

The young emperor's visit to the University of Tartu a month later (on May 22 ${ }^{\text {nd }}$ ) resulted in a new development, which provided an unexpected opportunity. An emotional welcoming speech by

6 PSZ, I, nr. 20104.

7 Tartu Ülikooli ajalugu $=$ University of Tartu History, vol. 2, ed. by Karl Siilivask (Tallinn: Valgus, 1982), 35-36. 
Georg Friedrich Parrot (1767-1852), Professor of Physics, ${ }^{8}$ impressed the Emperor, and the special friendship between the emperor and the professor which started then ${ }^{9}$ gave the professors of the University of Tartu the opportunity to compile a new version of the statutes that satisfied them. The document was initially developed together with the knighthoods' board of curators, ${ }^{10}$ but the right to employ professors proved to be an insurmountable issue - the board of curators wished to keep that right, while the professors wanted to expand their ranks themselves. The board of curators and professors both wished to have jurisdiction over the members of the university, ${ }^{11}$ but as it later turned out, this term was defined very differently by two sides.

The persona and world view of G. F. Parrot, which corresponded to the liberal ideas and hopeful spirit of the early reign of the Enlightenment-educated Alexander I, played a decisive role in the pursuit of fundamental changes. The history of the University of Tartu's Imperial Foundation Act and the new statutes has been best described by Fr. Bienemann ${ }^{12}$ and I will not discuss that subject in depth. Let us just say that it was Parrot's lobbying in St Petersburg that led to the emperor issuing a new foundation act on 12 December $1802,{ }^{13}$ which turned the University of Tartu into a Russian state university financed directly from the national treasury, and subject to the Ministry of National Education, which had been created just a few months before. The enactment of the Foundation Act of the University of Tartu went hand-in-hand with the development of a protocol for the other Russian universities subject to the Ministry of National Education, by serving as an

8 Printed for example in G. F. Parroti 200ndale sünni-aastapäevale pühendatud teadusliku konverentsi materjale (Tartu: Tartu Riiklik Ülikool, 1967), 221-222.

9 See for example, Friedrich Bienemann, Der Dorpater Professor Georg Friedrich Parrot und Kaiser Alexander I (Reval: Franz Kluge, 1902); Linda Eringson, Peeter Müürsepp, 'G. F. Parrot ja Tartu Ülikool', G. F. Parroti 200ndale sünni-aastapäevale pühendatud teadusliku konverentsi materjale (Tartu: Tartu Riiklik Ülikool, 1967), 9-25.

10 See for example, Marju Luts, 'Vaimude veerandtund rüütelkondade kuratooriumiga', Ajalooline Ajakiri, 1/2 (116/117) (2002), 24-30.

11 Bienemann, Dorpater Professor Georg Friedrich Parrot und Kaiser Alexander I, 102.

12 Ibidem.

13 Ukaz 12.12.1802. PSZ, I, nr. 20551. 
example. ${ }^{14}$ Although both the emperor and minister had doubts about whether giving the universities the right to administer justice was consistent with the principles of the Enlightenment, which aimed to unify the state and decrease the gap between the classes, Parrot managed to convince everyone that this would serve a noble cause - it would guarantee the University of Tartu a persecution-free existence ${ }^{15}$ and enable it to serve as an example for others.

The knighthoods' board of curators was pushed aside from the ruling position at the university and had to be content with managing the manors that had been donated to the university, but even that soon became unnecessary. In 1803, the emperor approved new statutes ${ }^{16}$ which the council of professors under Parrot had compiled themselves. The list of privileges was supplemented and provided the professors compensation for their accommodation expenses and freed them from censorship. The university's local government rights were extended - the council of professors now had the right to employ professors as well as elect a rector; in addition, the university was given autonomy in administering justice. Let us take a closer look at the professors' privileges.

\section{TAX EXEMPTION}

In the early $19^{\text {th }}$ century, Russian society was primarily divided into four classes: the nobility, the clergy, the citizenry and the peasants. While the French Revolution led to the dismantling of class society in Europe, it continued to be in effect in Russia and the Baltic provinces until the Revolutions of 1917.

The class divisions in the Baltic provinces were strengthened by ethnic segregation - the nobility, citizenry and clergy were

\footnotetext{
14 Julia E. Gracheva, 'Ustav Rossijskih Universitetov 1804. g.: Istorija podgotovki v ministerstve prosvesshtshenija', Klio (October, 2017), 40-46; Irina A. Gavrilina, 'Rektor G. F. Parrot i popechitel F. M. Klinger. Dva vzgljada na razvitije Derptskogo universiteta v pervye gody ego sushtshestvovanija (1802-1803)', Klio (October, 2017), 47-56.

15 ... assurez lui une existence exempte de tracasseries. Bienemann, Dorpater Professor Georg Friedrich Parrot und Kaiser Alexander I, 152.

16 The statutes are printed in Statuten der Kaiserlichen Universität zu Dorpat (Dorpat: M. G. Grenzius, 1803), but the confirmation is lacking in the PSZ.
} 
mainly German-speaking, while the simple townsfolk and peasants spoke Estonian (or Latvian in the Latvian territories). Although the Estonian and Livonian provinces had been a part of the Russian Empire since 1710 (Courland since 1797), the local class arrangements had a series of unique traits as compared to the rest of Russia, the most important being the existence of a separate class for men of letters (Literaten). ${ }^{17}$ A man of letters was a university-educated person, which in the early $19^{\text {th }}$ century mostly meant lawyers, clergymen and doctors. Men of letters were usually middle-class, and not nobles or peasants. Naturally, the university professors were also considered to be men of letters. They became a sort of fifth class in addition to the nobility, citizenry, clergy and peasantry and, in certain instances, this was taken into consideration by the Russian state (although no legal regulations existed).

The classes were divided in two groups in the Russian Empire - those subject to poll tax and those exempt from it. In 1783, the poll tax was also expanded to Baltic governorates. ${ }^{18}$ The nobility, men of letters, clergy and civil servants were exempt from the tax. Citizens (merchants and craftsmen), labourers living in the towns and peasants had to pay the tax. The merchants paid a guild tax according to their financial standing and their movements were not subject to restrictions. Craftsmen, labourers and peasants were subject to poll tax and conscription duty, and therefore, the state police kept a sharp eye on their numbers and movement. At the beginning of the $19^{\text {th }}$ century, the peasants were still serfs so, in practice, their tax was paid by the landowners. However, even after the abolishment of serfdom in 1816/19 the peasants remained dependent on the landowners and communities.

Those who were able to get an education (become men of letters) and/or become civil servants could be exempted from the tax. Anyone whose profession was on the list of Russian civil service ranks was exempted from poll tax during their service. The Russian Empire tried to make civil servants into a closed class by restricting people of other classes from entering the civil service. However,

17 Most in-depth study: Wilhelm Lenz, Baltischer Literatenstand (Marburg: Johann-GottfriedHerder-Institut, 1953).

18 Ukaz 23.08.1783. PSZ, I, nr. 15820. 
owing to the necessities of real life, people did manage to find ways to enter the civil service. ${ }^{19}$

Tax exemption meant much more than simply paying or not paying a single tax. People exempted from tax could also not be subjected to corporal punishment, their children could become civil servants or attend universities (those subject to poll tax needed special permission to do so, since a taxpayer would be lost this way). Thus, the professors' tax exemption defined them as the elite in the eyes of society and gave their children a better start in life. A professor's uniform included sword as a sign of a free person.

\section{SERVICE RANK}

The Table of Ranks was introduced in Russia in 1722 by Peter the Great. Initially, everyone whose profession was included in the Table of Ranks received the rights of personal (non-hereditary) nobility and, by climbing the ranks, could acquire a hereditary title. A pension system was also connected to rank - by serving for a certain number of years it was possible to get a state pension. However, this was not a common practice, since there was a limited amount allocated for pensions in the treasury. Later, the rank required for obtaining hereditary nobility was raised several times until, in the second half of the $19^{\text {th }}$ century, obtaining nobility by moving up the Table of Ranks became essentially impossible. However, the rule that a civil servant would be exempt from taxes remained in effect until the downfall of the Empire. In the early $19^{\text {th }}$ century, most professions requiring an education were included in the civil service system and this allowed one to obtain personal nobility at least. Foreigners were not usually accepted into the civil service in Russia, but the educational professions were an exception.

Until 11 June 1845, the $8^{\text {th }}$ civil rank (Collegiate assessor) provided hereditary nobility. In order to achieve that rank, between 1809 and 1834 , one had to present a university graduation diploma or pass a corresponding exam at one of the Russian universities. ${ }^{20}$ However, hereditary nobility was not granted instantly, but usually

19 Tatjana G. Arhipova, Marina F. Rumjantseva, Aleksandr S. Senin, Istorija gosudarstvennoj sluzhby v Rossii XVII-XX veka (Moskva: RGGU, 1999), 83; Ukaz 14.08.1798. PSZ, I, nr. 18622.

20 Arhipova, Rumjantseva, Senin, Istorija gosudarstvennoj sluzhby, 102. 
after serving a set number of years in the respective rank (the number of years changed over time). A university professor would be granted the $7^{\text {th }}$ rank (Court councillor or Hofrat) and, after 25 years of service, could expect both a state pension and nobility. The family of a professor who died in service received a pension from the Russian state, the amount of which depended on the rank, number of service years and awards received. Therefore, being a civil servant in Russia was a powerful stimulus, since most people working as lecturers in German universities, for instance, would never have had the chance to achieve hereditary nobility, and the death of the family head could, at a time when no social insurance existed, often mean that the family would find itself in dire straits. At the same time, upon the death of their father, the underage children of a University of Tartu professor would receive support until their coming of age (or marriage, in the case of the daughters).

\section{EXEMPTION FROM THE DUTY TO BILLET SOLDIERS}

The duty to billet soldiers was a state duty that applied to all those liable to taxation. Initially, this actually meant billeting any troops moving through the city, or sometimes even the resident garrison, in citizens' houses. Later this was replaced by a tax imposed by the city treasury, which was used to build and maintain separate military barracks.

Based on the 1799 plan, the professors' houses were already to be exempted from the billeting requirement. This was also confirmed by the Imperial Foundation Act of 12 December 1802, whereby all buildings owned by the university and its professors were exempted from military billeting duty. Later this was expanded to include houses owned or rented by teachers and officials (provided they lived in those buildings). ${ }^{21}$

Since the exemption also extended to houses rented by professors, it provided an additional stimulus for citizens to rent buildings to university members. In time this arrangement created ever greater tensions between the university and the town, especially since it was seen as an opportunity to evade policing duties, such as

21 Ukaz 04.05.1799. PSZ, I, nr. 18953; 12.12.1802. PSZ, I, nr. 20551. 
cleaning, lighting and paving the streets, firefighting etc. In order to end the confusion in the matter, the Baltic Governor-General enacted the Imperial Order of 16 November 1829, which stated that officials in the field of teaching were no longer exempt from policing duties (to be perfectly clear, the privilege never actually existed), but the exemption from military billeting duty remained in effect. ${ }^{22}$ In Tartu at that time, this no longer meant providing actual accommodation, but rather paying tax to the city that was used to maintain the military barracks.

\section{FREEDOM FROM CENSORSHIP}

In contrast to the reign of Paul I, who tried to cut Russia off from the West, censorship rules became much more relaxed at the beginning of the liberal reign of Alexander I (they would become stricter again later on). The Ukase of 5 January 1802 gave the university partial freedom from censorship - the university had its own censorship committee and could freely order books from abroad. ${ }^{23}$ According to the 1803 statutes, censorship issues were within the competence of a council of regular professors. The university became the censorship centre of the school district (the Tartu school district encompassed the governorates of Estonia, Livonia, Courland and, after 1811, Finland). The university's censorship committee consisted of the rector and deans, and all the professors were included as specialists. All manuscripts to be published in the district, as well as any books ordered from abroad, would be sent to the university for review. The professors' writings were not censored, neither was the foreign literature they ordered. ${ }^{24}$ The liberal spirit of the university's censorship committee has been highly valued in regard to its impact on the spread of Enlightenment literature. It is understandable that censoring all of the literature published in the school district (incl. educational writings in Estonian and Latvian, calendars etc.) was very time-consuming and became an obligation that the professors would have loved to be free of. The rules also became stricter

22 Ukaz 16.11.1829. National Archives of Estonia [Rahvusarhiiv, RA, EAA].402.4.63, 108-109.

23 Tartu Ülikooli ajalugu, II, 35; Ukaz 05.01.1802. PSZ, I, nr. 20104.

24 Tartu Ülikooli ajalugu, II, 43. 
as time passed, and in 1826 (reign of Nicholas I), the university's censorship committee was replaced by an establishment headed by the curator. ${ }^{25}$

\section{COMPREHENSIVE SCHOOL AND SCHOOL SUPERVISION}

The most complete realisation of Enlightenment-era principles can be seen in the comprehensive school plan announced in early 1803 . Parrot was an ardent supporter of this system. The state was to build a standardised system of parochial schools, district schools (in district centres), secondary schools (in governorate centres) and universities. The university headed up the educational hierarchy and was the centre of the school district. The governorates' school principals (who were appointed by the emperor after a motion was filed by the respective university) had to exercise state supervision over the schools. This role was often filled by university professors. Professors were also obligated to visit the schools every year. ${ }^{26}$

In Tartu, a school committee consisting of professors was created to deal with the schools, and this had a great impact on the founding and supervision of the schools in the region. However, since according to the plan, the lowest level (local) schools had to be financed by the communities (supposedly interested in providing education, in reality full of conflicting interests), the lowest level of comprehensive education - the parish school - was not established. And therefore, the school districts' educational facilities consisted of only town-based district schools and secondary schools, ${ }^{27}$ which made it nearly impossible for the peasants to enter the system. In 1820, the University of Tartu statutes already recorded the transition back to a rank-based school system. However, this does not diminish the meaningful role played by the professors in early $19^{\text {th }}$ century -

25 See: Lea Leppik, Rektor Ewers (Tartu: Eesti Ajalooarhiiv, 2001), 167.

26 Predvaritel'nye pravila narodnogo proshveshtshenija 24.01.1804. PSZ, I, nr. 20597, 20598.

27 For example, the special statutes for the district schools under the University of Tartu have been elaborated in the following: Modificationen der Allerhöchst ertheilten Statuten der Lehranstalten, welche den Universitäten untergeordnet sind, für die Kreis-Schulen, welche unter der Direction der Kaiserlichen Universität zu Dorpat stehen. St. Petersburg, den 31sten August 1806 (Dorpat: M. G. Grenzius, 1806). 
they were at the top of educational hierarchy and fully responsible for everything happening at the lower levels.

\section{THE UNIVERSITY'S AUTONOMY}

With great responsibility comes great trust. The university's autonomous position meant that it a) had its own jurisdiction over university members and b) the university council which consisted of professors had the right to award degrees, elect a rector and deans, and employ new professors. The Protestant university plan of 1799 did not intend to give the University of Tartu the right to administer justice; and had this plan been realised, the university members would have been under the jurisdiction of the local courts. However, the 1802 Imperial Foundation Act gave the university complete rights of self-government and its own jurisdiction. All the university members - this included the students, professors with their families and servants - were under the jurisdiction of the university's court. In 1810, there were 338 such persons, ${ }^{28}$ not counting the students. Tartu also served as a model for the autonomy that was included in the Russian universities' overall statutes in 1804, since Parrot had managed to convince the emperor of its necessity. ${ }^{29}$ However, full judicial autonomy only developed in Tartu. The new general statutes of 1835 abolished the right everywhere else, while the university court continued to be active in Tartu until 1889.

In order to understand why enlightened professors valued this rather medieval institution, we need to take a look at the developments at the German universities. In the Middle Ages, universities were of a monastic, and the university courts of a corporate and clerical, nature. ${ }^{30}$ During the Reformation, the territorial rulers (Landesherren) started to play an increasing role. They would decide whether the university had only limited lower judicial rights or whether its power extended to matters of

28 Lea Leppik. Kalefaktoripojast professoriks (Tartu: Kleio, 2011), 313-326; RA, EAA.402.8.184.

29 Gracheva, 'Ustav Rossijskih Universitetov 1804. g.: Istorija podgotovki v ministerstve prosvesshtshenija', 44.

30 Friedrich Stein, Die akademische Gerichtsbarkeit in Deutschland (Leipzig: Hirschfeld, 1891), 86 . 
life and death. State subsidies, courtesy of the territorial lords, started to influence the appointment of professors and teaching. The professors' judicial power over the students was largely disciplinary and was meant to continue the upbringing they received at home. Starting in the second half of the $17^{\text {th }}$ century, the academic judicial power exercised over the students began to be seen as a privilege. The professors' courts began to be viewed as state judicial institutions and the jurisdiction of such courts could extend beyond the students to other population groups. Since the rector was also the chief justice, it was considered natural that he was appointed by the territorial lord. Here we can see the interests of the knighthoods' board of curators at the University of Tartu at play, i.e. their control over appointing the university head, the teaching content, etc.

Some German universities (incl. Kiel, Halle and Göttingen) had been granted complete judicial power (über Leben und Tot) by their respective territorial lords, who thereby tried to achieve a competitive advantage. The founders of the University of Tartu saw Göttingen as an example. However, the courts began to disappear from the German universities in early $19^{\text {th }}$ century. In some places, they were abolished during the Napoleonic Wars, e.g., in the Kingdom of Westphalia. The academic courts in Germany were abolished for good after the Revolution of $1848 .{ }^{31}$

In other words, the University of Tartu (and, following its example, the other Russian universities) acquired judicial autonomy at a time when it began to go out of style in the West. It was favoured by the Enlightenment-minded professors, whose main motive seems to have been the desire to be subjected as directly as possible to the Russian Emperor and to be less dependent on the local government of nobles. The government viewed autonomy as a privilege that had to be earned, and as soon as the university got into trouble, its autonomy would be curbed. The university students had already been temporarily placed under the jurisdiction of the town police in 1808. Since judicial autonomy entailed additional obligations, some of the professors were quite content with the government restrictions. When, in 1816, the university council discussed an order that would extend the jurisdiction of the town police

31 Stein, Die akademische Gerichtsbarkeit in Deutschland, 119-120, 126-129, 137. 
over the students 'at His Majesty's pleasure', most of the council members were ready to agree. Gustav Ewers (1779-1830), the longserving Rector of the University (Professor of History, Statistics and Geography 1810-1826, Professor of Constitutional Law 18261830, Rector 1818-1830) clearly stated why the university needed autonomy: 'In all the new European states that excel in education, that education has stemmed from universities. Their influence has considerably increased after a political corporation was formed - a new citizen rank that sets itself apart from the other classes based on its mental aspirations and knowledge. The Russian Emperor probably had something similar in mind. Personal jurisdiction is not a privilege - it is a precondition of the university's influence. The more immature the state, the more such institutions need liberties and privileges; first to keep unclean hands off them, and secondly, so that uneducated people, who only see the exterior, will understand the value of science - something that can only be measured with a yardstick provided by the highest state authority. ${ }^{\prime 2}$

\section{UNIVERSITY'S LOCATION IN THE CITY}

With all the privileges it was granted, one would think that the university and its professors would also try separate themselves in the cityscape as well. In reality, Tartu proved the opposite. It remained an open city. The city was not encircled by a wall (the medieval town walls had been destroyed back in the wars in the early $18^{\text {th }}$ century, and the rubble had been used as building material in subsequent years). In 1799, Emperor Paul I gifted the lands that had previously been owned by the Tartu garrison, including Toomemägi Hill and the site of St. Mary's Church, to the future University of Tartu. The territory almost equalled the size of the town of Tartu at the time. Had the university's creators wished to do so, they could have easily fit the entire university, including the professors' houses and student dormitories, into that area. However, the board of curators decided to distribute the lands on the foot of Toomemägi Hill as lots (firstly as gardening plots, ${ }^{33}$ and later for

32 Leppik, Rektor Ewers, 137; RA, EAA.402.6.329, 28-34.

33 Report of the building committee 8.04.1804. RA, EAA.402.5.45, 19v. 
housing), so that the income could support the university. In 1803, slightly more than one third (38\%) of the lots belonged to members of the university. ${ }^{34}$ This pragmatic solution remained in effect even after the leadership of the university was taken over by enlightened professors and the funding came directly from the state. Until 1940 the rent from these lots (obrok) remained a substantial part of the university's special funds, and was used to hire private associate professors, support publishing activities and research trips, etc.

The university's buildings (library, anatomical theatre, clinic, old observatory) were constructed on top of Toomemägi Hill and surrounded by a park. The owners of the hillside lots built fences around their land and these fences became the borders of the park. ${ }^{35}$ The park had no locked gate or enclosure. This open space was an element of the belief shared by the park's creators (especially professor G. F. Parrot) that the temple of sciences had to be surrounded by a sanctuary of nature open to people of all standings, who would work together to help the University of Tartu produce great men. ${ }^{36}$ The park's educational purpose was strengthened by a rule established in October 1803, which stated that pubs could be not built on the hillside lots and it was prohibited to sell alcohol there. Exceptions were not even made during largescale construction projects, when an application was made to build a temporary pub for the workers, and for at least several decades nobody was allowed to sell alcohol on the university's property. ${ }^{37}$

The first University of Tartu professors were often young fortune seekers with no great riches; many had started their careers as private tutors in Livonia. Initially most lived in rented houses or apartments. Logically, everyone tried to find a place as close as possible to the city centre and the university's main building. There was no talk of creating a separate campus in Tartu, even

34 Based on the map: RA, EAA.2100.11.133, 13a; See also Lea Leppik, 'Kus elas Tartu professor?', Johann Wilhelm Krause 1757-1828, kataloog 4: ülikool Emajõe Ateenas = Die Universität im Embach-Athen, ed. by Juhan Maiste, Anu Ormisson-Lahe (Tartu, Tallinn: Tartu Ülikool, Eesti Keele Sihtasutus, 2016), 453-482.

35 Anu Ormisson Lahe, 'Toomemäe park / Der Park auf dem Dom', Johann Wilhelm Krause 1757-1828, kataloog 3: linnaehitajana Tartus $=$ Als Stadtbauer in Tartu, ed. by Juhan Maiste, Anu Ormisson-Lahe (Tartu, Tallinn: Tartu Ülikool, Eesti Keele Sihtasutus, 2011), 333-366.

36 Epi Tohvri, Valgustusideede mõju Tartu arhitektuurikultuurile. Dissertationes historiae Universitatis Tartuensis, 18 (Tartu: Tartu Ülikooli Kirjastus, 2009), 271.

37 RA, EAA.402.4.123. 
though the vacant university-owned Toomemägi Hill would have made it possible. The town's small size and the fact that learned men belonged to the class of men of letters (and their juxtaposition to the merchants and craftsmen) promoted active communication within the university community and isolation from the rest of the townsfolk, which meant that there was definitely a mental academic village in Tartu. Several professors' families would often lease a house together and sometimes even students would be taken in as tenants. By the end of their service, many (both the professors and civil servants of university) would have their own houses, and depending on the owner's taste, the interiors could be quite luxurious or austere, but usually appropriate for Tartu's social lifestyle. The professors' houses were mostly clustered in two new neighbourhoods near Toomemägi Hill and the university's main building. A few of them acquired properties in the old town centre, so it could be said they were trendsetters and followers of a modern urban lifestyle. The privileges that were granted to the university based on its statutes favoured the creation of a separate community and tense, rather than friendly, relations with the ordinary citizens of Tartu. ${ }^{38} \mathrm{~A}$ professor was a prominent figure in a small $19^{\text {th }}$ century university town. For example, the majority of the subjects in the humourist Dr Bertram's Dorpats Grössen und Typen are university professors, alongside a merchant, veterinarian and police chief. ${ }^{39}$

\section{IN CONCLUSION}

According to the tasks established in the 1803 statues, the position of professor was extremely important - sometimes even too important for the professors to bear. The early $19^{\text {th }}$ century Russian university model tried to satisfy the state's practical needs and offer useful education by putting the universities at the top of the educational system and making its professors priests of the Enlightenment, who were responsible for educating the youth at all school levels, free

38 Leppik, 'Kus elas Tartu professor?', 474-475.

39 Dr. Bertram [Georg Julius von Schultz], Dorpats Grössen und Typen vor vierzig Jahren (Dorpat: Gläser, 1868). 
from economic concerns and without fear for the future. Teaching had to be connected to scientific research; use of funds was to be coordinated with the Ministry of National Education via the curator. A professor was first and foremost responsible for his actions before a higher power - the emperor - and not the local corporations. The reality proved to be less lofty. Creating a comprehensive school did not work in a class-based society, wartime inflation depleted professors' salaries, and not everyone attained the high moral and spiritual level expected of them. Corporate reclusion in the form of a number of privileges and judicial autonomy were not really part of the Enlightenment-era principles that valued unity and the dismantling of the classes. However, in Tartu they did help the university and its professors become the carriers of Enlightenment ideas and protected them from the rest of the society. It would be too much to claim that each and every one of them became a priest of the Enlightenment; however, together they did made Tartu into an outstanding university town.

Lea Leppik: University of Tartu Professor in the University Landscape (in the First Third of the $19^{\text {Th }}$ Century)

KeYWORDS: UNIVERSITY OF TARTU; PROFESSORS' RESIDENCES; ENLIGHTENMENT; LEGAL RIGHTS OF THE PROFESSORS; $19^{\text {TH }}$ CENTURY URBAN ARCHITECTURE; UNIVERSITY LANDSCAPE

LeA LePpiK is the Research Director at the University of Tartu Museum and Associate Professor in Legal History at the University of Tartu. Received her PhD at the University of Tartu (2006) on the topic Social mobility of the employees of the University of Tartu (18021918). Her research focuses on the history of the University of Tartu 
and Estonian science, mostly in the $19^{\text {th }}$ and $20^{\text {th }}$ centuries, and biographies of scientists and social mobility. Since 2004, she has been editor-in-chief of the series of publications in university and science history entitled Tartu Ülikooli ajaloo küsimusi. Leppik is also a member of the council of the Tartu City Museum (since 2007). Main publications include: Rektor Ewers (2002) and Kalefaktoripojast professoriks (2011), both of which have been nominated for the annual prize in Estonian history writing. 